\author{
Dr hab. Mirosława KOZLOWSKA-BURDZIAK, prof. UwB \\ Wydział Ekonomii i Zarządzania, Uniwersytet w Białymstoku \\ e-mail: m.kozlowska@uwb.edu.pl \\ ORCID: 0000-0002-2274-2617
}

DOI: $10.15290 /$ oes.2019.03.97.03

\title{
WARUNKI BEZPIECZEŃSTWA ŻYWNOŚCIOWEGO POLSKI (ZE SZCZEGÓLNYM UWZGLĘDNIENIEM WOJEWÓDZTWA PODLASKIEGO) ${ }^{1}$
}

\begin{abstract}
Streszczenie
Cel - Celem artykułu jest określenie głównych tendencji w zakresie kształtowania się bezpieczeństwa żywnościowego w gospodarce Polski, ze szczególnym uwzględnieniem w tej kwestii roli województwa podlaskiego.

Metoda badań - Analizę przeprowadzono w oparciu o dane GUS, Państwowej Inspekcji Sanitarnej, Inspekcji Jakości Handlowej Artykułów Rolno-Spożywczych oraz studia literaturowe dotyczące poruszanej problematyki.

Wnioski - W wyniku przeprowadzonej analizy stwierdzono, że ze względu na malejącą liczbę ludności i rosnącą dynamikę produkcji żywności jej fizyczna dostępność nie jest zagrożona. Istotną rolę w produkcji żywności odgrywa województwo podlaskie. Warunek dostępności ekonomicznej żywności zarówno w kraju, jak i w województwie podlaskim nie jest spełniony. Jakość zdrowotna produktów rolno-spożywczych w Polsce jest zróżnicowana i nie ma trwałej tendencji do poprawy, co obliguje do stałego jej monitorowania przez powołane do tego celu instytucje. W ostatnich latach zwiększa się także liczba zafałszowań żywności. Przedstawione w artykule tendencje w zakresie bezpieczeństwa żywnościowego dowodzą, że problematyka jest ważna i ciagle aktualna. Mimo braku wyraźnych zagrożeń dla poziomu tego bezpieczeństwa w Polsce należy mieć na uwadze fakt, że nie jest to sytuacja stała i niezmienna, także w przyszłym okresie.
\end{abstract}

Słowa kluczowe: bezpieczeństwo żywnościowe, fizyczna i ekonomiczna dostępność żywności, jakość żywności, Polska, województwo podlaskie

\section{CONDITIONS FOR THE FOOD SECURITY OF POLAND (WITH SPECIAL CONSIDERATION OF THE PODLASIE VOIVODESHIP)}

\section{Summary}

Purpose - The article aims to define main tendencies concerning the structure of food safety within the economy of Poland with special consideration of the Podlasie Voivodeship.

1 Artykuł wpłyną 9 grudnia 2018 r., zaakceptowano 6 maja 2019 r.

Article received 9 December 2018, accepted 6 May 2019. 
Research method - The analysis was conducted on the basis of data obtained from the Central Statistical Office of Poland (GUS), the State Sanitary Inspectorate, the Office of the Chief Inspector of Food and Agricultural Products as well as the study of literature related to the issue being considered.

Results - The analysis established that on account of decreasing levels of population and the growing capabilities for food production its physical availability is not threatened. The Podlasie Voivodeships plays a significant role in food production. The condition of economic availability of food both nationally as well as in the Podlasie Voivodeship has not been met. Health related quality of agriculturally produced food is varied and does not display a steady tendency for improvement which requires appropriate institutions to remain vigilant in monitoring it. The last several years have seen a rise in the number 4 of food fraud cases. The tendencies concerning food safety presented in the article prove that the subject remains important and valid. Despite the lack of a clear threat to the level of that safety in Poland, it must be remembered that this situation is not stable or unchangeable, a condition which also concerns the future.

Key words: food security, physical and economic availability of food, food quality, Poland, Podlasie Voivodeship

JEL classification: Q18

\section{Wstęp}

Ze względu na rolę żywności w życiu człowieka, zapewnienie bezpieczeństwa żywnościowego jest niewątpliwie jednym z najważniejszych problemów współczesnego świata. Przewiduje się, że liczba ludności na świecie do roku 2050 wzrośnie o 30\% w porównaniu do roku 2012 i wyniesie 9 mld. W związku z tym globalne zapotrzebowanie na żywność może się zwiększyć nawet o 70\% [Innowacje w stu̇̌bie..., 2012]. W szczególności zwiększy się zapotrzebowanie na mięso. Zapewnienie wystarczającej ilości żywności o określonej jakości, dostępnej dla każdego człowieka, w warunkach ograniczoności zasobów naturalnych jest niewattpliwie jednym z największych wyzwań zarówno w wymiarze globalnym, jak i lokalnym. Główne zagrożenia $\mathrm{w}$ tym obszarze wiążą się ponadto $\mathrm{z}$ ryzykiem spowolnienia wzrostu wydajności produkcji roślinnej i zwierzęcej, zmianami cen żywności oraz zmianami w strukturze spożycia [Sustainable Agriculture..., 2015, s. 49]. Rolnictwo i przemysł przetwórczy województwa podlaskiego odgrywają znaczącą rolę w produkcji żywności na rynek krajowy i zagraniczny. Zwraca jednak uwagę stosunkowo wysoki w województwie podlaskim wskaźnik skrajnego ubóstwa, określany także jako minimum egzystencji. Stanowi to zagrożenie dla ekonomicznego dostępu do żywności dla znacznej grupy konsumentów w tym województwie.

\section{Materiał i metodyka badań}

Celem opracowania jest określenie głównych tendencji w zakresie kształtowania się bezpieczeństwa żywnościowego w gospodarce Polski ze szczególnym uwzględnieniem produkcji żywności w województwie podlaskim. Poprzez bezpieczeństwo żywnościowe należy rozumieć trzy podstawowe jego wymiary: fizyczną dostępność żywności, dostępność ekonomiczną oraz jej jakość zdrowotna, w głównej mierze 
składającą się na bezpieczeństwo żywności. Analizie poddano także jakość handlową produktów żywnościowych, analizowaną przez Inspekcję Handlową Artykułów Rolno-Spożywczych.

$\mathrm{W}$ analizie wykorzystano dane zawarte $\mathrm{w}$ sprawozdaniach podstawowych instytucji sprawujących w Polsce nadzór nad bezpieczeństwem żywności - Państwowej Inspekcji Sanitarnej i Inspekcji Weterynaryjnej, IHARS, dane GUS oraz opracowania naukowe IERiGŻ-PIB dotyczące poruszanej problematyki.

\section{Pojęcie i warunki bezpieczeństwa żywnościowego}

W związku ze strategiczną rolą żywności w życiu człowieka, od zawsze dążył on do tego, by nigdy mu jej nie zabrakło. Początkowo bezpieczeństwo żywnościowe przejawiało się $\mathrm{w}$ trosce o zabezpieczenie zapasów żywności na wypadek klęski głodu, później jego zakres objął wszystkie - także najuboższe - warstwy społeczeństwa. Rozwój nauki o żywieniu sprawił, że bezpieczeństwo żywnościowe, oprócz wolumenu żywności, dotyczy obecnie także jakości zdrowotnej poszczególnych produktów i składającej się z nich racji żywnościowej².

Definicja bezpieczeństwa żywnościowego poczattowo sprowadzana była zatem do dwóch warunków: dostępności fizycznej i dostępności ekonomicznej. Dostępność fizyczna oznacza posiadanie wystarczającej ilości dostępnej żywności dla całej ludności w każdym czasie, aby można było podtrzymać życie ludzkie. Dostępność ekonomiczna wiąże się z możliwością nabycia żywności przez wszystkie grupy społeczne - nawet te najuboższe [Marzęda-Młynarska, 2014, s. 95].

J. Małysz zwraca uwage na trzeci wymiar bezpieczeństwa żywnościowego, jakim jest adekwatność [Małysz, 2009, s. 79]. Adekwatność rozumiana jest przede wszystkim w kategorii zbilansowanej racji pokarmowej. Należy jednak podkreślić, że adekwatna podaż żywności jest wolna od chorób i trujących substancji. W oparciu o wspomniane wyżej trzy warunki i wymiary bezpieczeństwa żywnościowego można określić cały system bezpieczeństwa żywnościowego (rysunek 1).

Bezpieczeństwo żywnościowe może być analizowane na kilku poziomach (wymiary bezpieczeństwa). Może być to bezpieczeństwo indywidualne lub rodziny, częściej określane jako bezpieczeństwo żywnościowe gospodarstw domowych, narodowe bezpieczeństwo żywnościowe oraz międzynarodowe bezpieczeństwo żywnościowe [Małysz, 2009, s. 80]. Zachodzacy proces globalizacji ekonomicznej uzasadnia pojawienie się pojęcia globalnego bezpieczeństwa żywnościowego [Kraciuk, 2015, s. 207].

W literaturze szczególną uwagę zwraca się na bezpieczeństwo żywnościowe gospodarstw domowych. Organizacja Narodów Zjednoczonych ds. Wyżywienia i Rolnictwa (FAO) definiuje je jako sytuację, w której wszystkie gospodarstwa domowe

2 Racja żywnościowa to zestaw produktów żywnościowych przewidzianych do spożycia przez jedną osobę w ciagu dnia, z uwzględnieniem potrzeb żywnościowych tej osoby (wiek, aktywność zawodowa, tradycja itp.). 
maja jednocześnie dostęp fizyczny i ekonomiczny do wystarczającej żywności dla wszystkich członków i nie istnieje ryzyko, że gospodarstwa domowe utraca ten dostęp [Małysz, 2009, s. 80].

\section{System bezpieczeństwa żywnościowego}

RYSUNEK 1

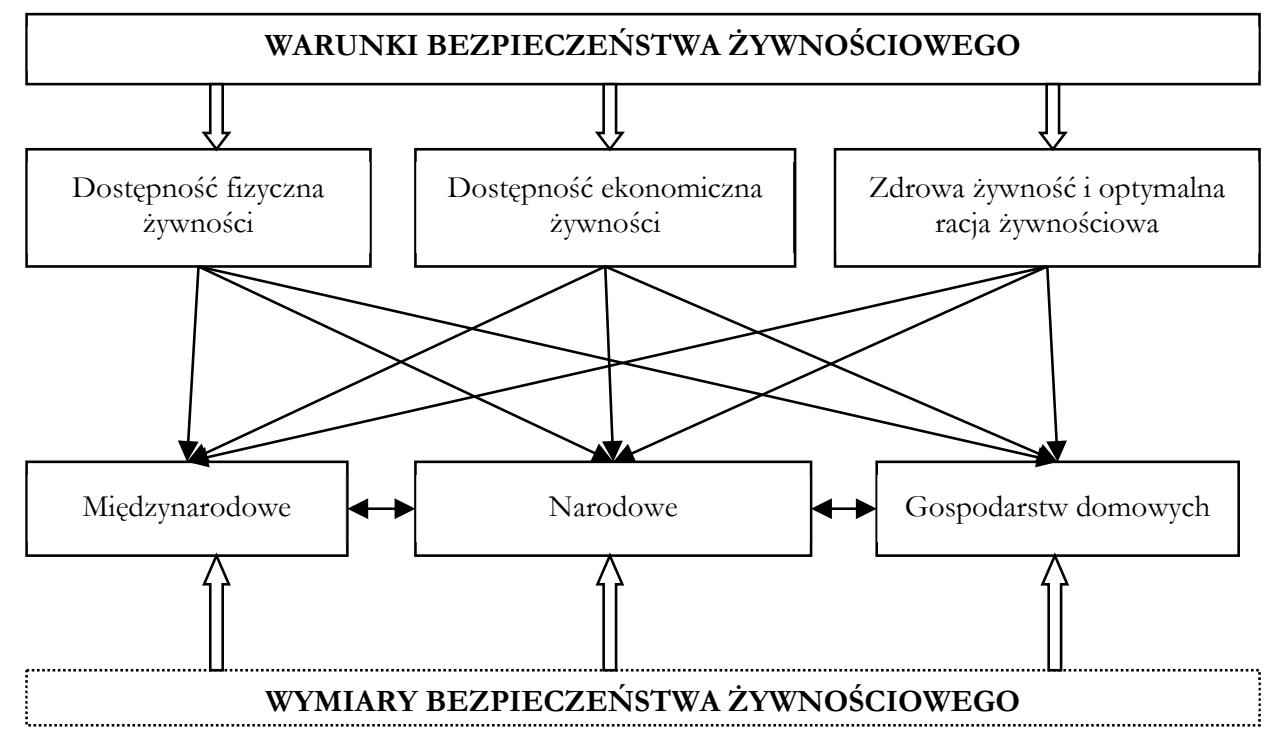

Źródło: [Małysz, 2009, s. 80].

Brak bezpieczeństwa żywnościowego na poziomie gospodarstwa domowego jest przyczyną jego zakłóceń także na poziomie całego kraju i na poziomie międzynarodowym. Szczególnie taka sytuacja występuje obecnie w krajach o najniższym poziomie rozwoju, dotkniętych przez klęski żywiołowe (długotrwałe susze), posiadających systemy polityczne wrogie demokracji i gospodarce rynkowej oraz targane przez konflikty zbrojne.

Wszystkie trzy wymiary bezpieczeństwa żywnościowego są zatem ze sobą ściśle powiązane. W wymiarze międzynarodowym powstają regionalne ugrupowania państw, których celem staje się zapewnienie bezpieczeństwa żywnościowego w skali regionu, przy czym deklarują one, że warunkiem koniecznym bezpieczeństwa regionalnego jest uprzednie osiagnięcie bezpieczeństwa narodowego członków tego ugrupowania [Małysz, 2009, s. 95].

Bezpieczeństwo żywnościowe nierozerwalnie wiąże się z jakością produktów żywnościowych. W tym kontekście możemy mówić o bezpieczeństwie żywności. Jest to zatem termin węższy od (omówionego wyżej) pojęcia bezpieczeństwa żywnościowego. Ustawa o bezpieczeństwie żywności i żywienia [Ustawa..., 2006] za „bezpieczeństwo żywności” przyjmuje ogół warunków, które muszą być spełnione, dotyczących w szczególności: 
- stosowanych substancji dodatkowych i aromatów,

- poziomu substancji zanieczyszczających,

- pozostałości pestycydów,

- warunków napromieniania żywności,

- cech organoleptycznych,

- działań, które muszą być podejmowane na wszystkich etapach produkcji lub obrotu żywnościa - w celu zapewnienia zdrowia i życia człowieka.

Zagrożeniem dla bezpieczeństwa żywności są szeroko rozumiane substancje zanieczyszczające produkty spożywcze i zanieczyszczenia żywności. Substancja zanieczyszczająca, zgodnie z Ustawą [2006] i Rozporządzeniem Rady (EWG) nr 315/93 [1993], to każda substancja nieumyślnie dodana do żywności, która jest obecna w takiej żywności jako rezultat produkcji, wytwarzania, przetwarzania, przygotowywania, obróbki, pakowania, opakowywania, transportu lub przechowywania żywności, jako rezultat skażenia środowiska.

Zanieczyszczenia żywności uznaje się za pojęcie szersze. Obejmuje ono: substancje zanieczyszczające, zanieczyszczenia biologiczne oraz ciała obce, szkodniki lub ich części. W przepisach prawa regulujących bezpieczeństwo żywności zanieczyszczenia utożsamiane są z pojęciem ,zagrożenie” [Wiśniewska, 2011, s. 39].

Jakość handlowa produktów rolno-spożywczych nie stanowi w wyżej przedstawionym zakresie warunku bezpieczeństwa żywnościowego. Niewatpliwie jest jednak bardzo istotna z punktu widzenia konsumenta i możliwości pełnego zaspakajania przez niego potrzeb żywieniowych. Analizowana jest pod kątem oceny organoleptycznej, cech fizykochemicznych oraz znakowania produktów i określana jako jakość ekonomiczna żywności [Kowalczyk, 2016, s. 174].

\section{Realizacja bezpieczeństwa żywnościowego w gospodarce Polski}

Jako pierwszy warunek bezpieczeństwa żywnościowego zwykle podaje się fizyczną dostępność żywności. W warunkach gospodarki otwartej ilość produktów żywnościowych dostępnych na rynku nie zależy od miejsca ich wytworzenia, tj. w kraju czy za granica. Miarą samowystarczalności żywnościowej kraju jest m.in. saldo bilansu handlowego produktami rolno-spożywczymi. Jednak gwarancją bezpieczeństwa żywnościowego, rozpatrywanego w aspekcie fizycznej dostępności, jest wolumen żywności niezbędny do zapewnienia minimalnego zapotrzebowania fizjologicznego ludności na środki spożywcze [Małysz, 2009, s. 85]. Istotne jest to, że wolumen ten musi pochodzić z krajowej gospodarki żywnościowej.

Dane dotyczące wartości produkcji końcowej w polskim rolnictwie w $2017 \mathrm{r}$. dowodza, że w porównaniu zarówno do 2005 r., jak i do 2010 r. istotnie ona wzrosła (odpowiednio o $85,6 \%$ oraz 39,9\%) - tabela 1 . Wzrost o prawie $9 \%$ notowany jest także w stosunku do 2016 r. Rok 2015 charakteryzował się niekorzystnymi warunkami atmosferycznymi, a tym samym i spadkiem produkcji rolniczej w porównaniu do $2013 \mathrm{r}$. 
W zakresie ogólnej fizycznej dostępności żywności nie występują więc zagrożenia związane z jej ewentualnym brakiem, tym bardziej, że dynamika salda handlu zagranicznego produktami rolno-spożywczymi jest wysoka i rosnąca (chociaż 2016 r. charakteryzował się spadkiem salda w odniesieniu do 2015 r.). Warta podkreślenia jest też malejąca po 2010 r. liczba ludności kraju. Opracowane w tym zakresie scenariusze do roku 2050 przewidują w każdym wariancie dalszy systematyczny spadek tej liczby. W wariancie najbardziej pesymistycznym może ona w 2050 r. wynieść zaledwie 32,1 mln osób, co oznacza spadek o 16,6\% w porównaniu do 2015 r. [Prognoza ludności..., 2014]. Wzrost liczby ludności w 2017 r. w porównaniu do roku poprzedniego o około 1 tys. mieszkańców naszego kraju w najmniejszym stopniu nie wpływa na spadek fizycznej dostępności żywności.

TABELA 1

Dynamika podstawowych danych charakteryzujących fizyczną dostępność żywności w Polsce w latach 2005-2017 (ceny bieżące, rok poprzedni=100\%)

\begin{tabular}{|l|c|c|c|c|c|c|c|c|}
\hline Wyszczególnienie & $\mathbf{2 0 0 5}$ & $\mathbf{2 0 1 0}$ & $\mathbf{2 0 1 3}$ & $\mathbf{2 0 1 5}$ & $\mathbf{2 0 1 6}$ & $\begin{array}{c}\mathbf{2 0 1 6} \\
\mathbf{1 0 0} \mathbf{0}\end{array}$ & $\begin{array}{c}\mathbf{2 0 0 5} \\
\mathbf{1 0 0} \%\end{array}$ & $\begin{array}{c}\mathbf{2 0 1 0} \\
\mathbf{1 0 0} \mathbf{0}\end{array}$ \\
\hline $\begin{array}{l}\text { Rolnicza produkcja } \\
\text { końcowa }\end{array}$ & 95,6 & 97,3 & 106,0 & 97,0 & 105,2 & 108,9 & 185,6 & 139,9 \\
\hline $\begin{array}{l}\text { Liczba ludności } \\
\text { ogółem }\end{array}$ & 99,9 & 100,9 & 99,9 & 99,9 & 99,9 & 100,0 & 100,7 & 99,8 \\
\hline $\begin{array}{l}\text { Rolnicza produkcja } \\
\text { końcowa } \\
\text { na 1 mieszkańca }\end{array}$ & 93,9 & 103,4 & 108,3 & 94,7 & 105,2 & 108,9 & 184,3 & 140,2 \\
\hline $\begin{array}{l}\text { Saldo handlu } \\
\text { zagranicznego } \\
\text { produktami } \\
\text { rolno-spożywczymi }\end{array}$ & 212,7 & 118,2 & 141,9 & 114,9 & 89,7 & 120,0 & 494,1 & 323,1 \\
\hline
\end{tabular}

Źródło: obliczenia własne na podstawie: [Rolnictwo..., 2007-2018; Ludność. Stan i struktura..., 2006-2018; Polski bandel zagraniczny..., 2018].

Niebagatelną rolę w produkcji żywności odgrywa województwo podlaskie. Według danych GUS w 2016 r. województwo podlaskie zajmowało [Rolnictwo w województwie..., 2017, s. 46-47]:

- $\quad 1$. miejsce w produkcji mleka na 1 ha UR - 2362l,

- 1. miejsce pod względem obsady bydła na 100 ha UR - 88,2 SD,

- 4. miejsce pod względem przeciętnego rocznego udoju mleka od jednej krowy (po województwach: opolskim, wielkopolskim, kujawsko-pomorskim) -58721 ,

- 6. miejsce pod względem wartości skupu produktów rolnych na 1 ha UR - 4131 zl, w roku 2017 wartość skupu produktów rolnych na 1 ha UR 
wyniosła 5055 zł, co dało województwu miejsce 3. (po województwach: wielkopolskim, mazowieckim).

Ponad połowę, bo 55,1\%, produkcji sprzedanej przemysłu w województwie podlaskim w 2016 r. stanowiła produkcja artykułów spożywczych. Należy podkreślić, że charakteryzuje ją widoczny wzrost: w 2016 r. produkcja sprzedana artykułów spożywczych wzrosła o $136 \% \mathrm{w}$ stosunku do 2005 r., o $45 \%$ w porównaniu do 2010 r., o 5,6\% w odniesieniu do 2015 r. [Rocznik statystyczny..., 2017, s. 301]. Województwo podlaskie pod względem udziału w produkcji towarowej rolnictwa zajmowało w 2016 r. miejsce szóste $(6,6 \%)$ pod względem wartości towarowej produkcji zwierzęcej tj. miejsce trzecie po województwie wielkopolskim i mazowieckim $(9,8 \%)$. Prawie $62 \%$ produkcji towarowej zwierzęcej stanowiła produkcja mleka w województwie podlaskim wytwarza się jedną piątą całej produkcji mleka w Polsce.

Specyfiką rolnictwa w województwie podlaskim jest wysoki udział produkcji zwierzęcej (stanowi ona ponad 90\% produkcji towarowej rolnictwa). Ma to swoje odzwierciedlenie w wynikach określających rolę województwa podlaskiego w krajowej produkcji żywności. Według danych GUS za 2016 r. [Rocznik statystyczny..., 2017, s. 303]:

- produkcja mleka płynnego, przetworzonego w województwie podlaskim stanowi 31,6\% produkcji krajowej,

- produkcja serów i twarogów - to $26,5 \%$ produkcji krajowej,

- $\quad$ masło i pozostałe tłuszcze do smarowania to $40,0 \%$ produkcji krajowej.

Badania przeprowadzone przez IERiGŻ PIB wykazały, że większość produktów żywnościowych, produkowanych w Polsce, spełnia wymogi samowystarczalności. Występuja jednak stałe niedobory produkcji nasion roślin strączkowych, oleistych oraz tłuszczy i olei roślinnych. W niektórych latach deficytem charakteryzuje się także produkcja mięsa wieprzowego [Z badań nad..., 2015, s. 35-96].

Istotnym wyznacznikiem fizycznej dostępności żywności są zapasy tworzone na wypadek zagrożenia bezpieczeństwa i obronności państwa, ale także w związku z możliwością wystąpienia klęsk żywiołowych lub sytuacji kryzysowych. Informacje o stanie rezerw strategicznych nie są wprawdzie jawne, jednak z tych, które docierają do społeczeństwa, wynika, że w przypadku ogólnokrajowego kataklizmu zapasy żywności w Polsce wystarczą zaledwie na kilka dni [Ćwieluch, 2011, s. 24-25]. Dodatkowo Najwyższa Izba Kontroli alarmuje, że nie są realizowane postanowienia ustawy o rezerwach strategicznych. Jeśli chodzi o produkty żywnościowe (obejmujące 24 pozycje) „w roku 2014 na sześć pozycji planowanych utworzono jedna w 75\% wielkości planowanej, pozostałe pozycje asortymentowe nie zostały utworzone; utworzono natomiast nieplanowaną rezerwę półtusz wieprzowych" [Polska nie ma..., 2016].

Kolejnym warunkiem bezpieczeństwa żywnościowego jest ekonomiczna dostępność żywności. Jest ona zapewniona wówczas, gdy wszystkie gospodarstwa domowe i każda osoba z takiego gospodarstwa dysponuje wystarczającymi zasobami, aby móc nabyć żywność w odpowiedniej ilości i jakości [Marzęda-Młynarska, 2014, s. 261]. 
Ekonomiczna dostępność żywności zarówno na poziomie kraju, jak i poszczególnych gospodarstw domowych, a także osób tworzących te gospodarstwa może być analizowana za pomocą wielu wskaźników, np. poziom dochodów, PKB per capita, współczynnik Giniego, który przedstawia zróżnicowanie dochodowe społeczeństwa, ceny żywności, poziom wydatków na żywność czy też udział wydatków na żywność w wydatkach ogółem.

Badania przeprowadzone przez IERiGŻ PIB z wykorzystaniem wyżej wspomnianych wskaźników pokazują, że [Z badań nad..., 2015, s. 35-96]:

- $\quad$ wzrasta przeciętny miesięczny dochód rozporządzalny w gospodarstwach domowych (za wyjątkiem gospodarstw rolnych w 2014 r.),

- poziom dochodu rozporządzalnego jest zróżnicowany - najwyższy w gospodarstwach osób pracujących na własny rachunek, najniższy w gospodarstwach rolników,

- w 2014 r. zmalało, w stosunku do lat poprzednich, zróżnicowanie dochodów na osobę w gospodarstwach domowych, mierzone współczynnikiem Giniego, co świadczy o malejącym rozwarstwieniu ekonomicznym polskiego społeczeństwa,

- $\quad$ we wszystkich grupach gospodarstw domowych maleje udział wydatków na żywność w wydatkach ogólem.

Powyższe zjawiska w pozytywny sposób świadczą o poprawie ekonomicznej dostępności żywności. Badania wykazały jednak także negatywne zjawiska, które tę dostępność znacznie ograniczaja. Wśród nich wymienić należy [Z badań nad..., 2015, s. 35-96]:

- $\quad$ strukturę spożycia poszczególnych produktów żywnościowych, nie zawsze zgodną z zaleceniami żywieniowymi, określonymi przez nauki o żywieniu,

- $\quad$ szybszy wzrost cen żywności niż ogólnych cen dóbr konsumpcyjnych i usług,

- $\quad$ wyższy wzrost cen żywności niż wzrost przeciętnego miesięcznego wynagrodzenia realnego brutto,

- $\quad$ istotny zasięg sfery ubóstwa ekonomicznego w Polsce.

Wprawdzie dane statystyczne informują o zmniejszaniu się sfery ubóstwa w Polsce w latach 2005-2014, to jednak poniżej granicy ubóstwa skrajnego (poniżej poziomu minimum egzystencji) żyło w Polsce w 2014 r. około 2,8 mln osób [Ubóstwo..., 2015, s. 1], w 2017 r. 1,6 mln. W 2015 r. 5,4\% gospodarstw domowych nie miało wystarczającej ilości pieniędzy na żywność [Jakość życia..., 2015, s. 6], w 2017 r. wskaźnik ten obniżył się do poziomu 4,3\%. Osoby o niskich dochodach w dalszym ciagu mają utrudniony dostęp do żywności, a przy rosnących cenach produktów żywnościowych ich sytuacja ulega dalszemu pogorszeniu. W takiej sytuacji informacje o marnotrawstwie żywności (w Polsce ponad $200 \mathrm{~kg}$ rocznie na osobę [Kwasek, 2016]) wymagają podjęcia zdecydowanych działań ograniczających to zjawisko. 
Wskaźnik ubóstwa skrajnego ${ }^{3}$ w województwie podlaskim w 2014 r. wynosił 10,9\% (trzecia lokata po województwach: warmińsko-mazurskim, świętokrzyskim). W stosunku do 2010 r. wskaźnik w 2014 r. uległ pogorszeniu o 1,8 p.p. W 2017 r. sytuacja w tym względzie uległa nieznacznej poprawie - wskaźnik obniżył się do poziomu 7,2\% [Aneks..., 2018].

W 2016 r. wskaźnik ubóstwa skrajnego w województwie podlaskim był wyjątkowo niski i wynosił 4,2\%, jednak sytuacji materialnej ludności nie można ocenić jako korzystnej. W dalszym ciagu za mniej niż 544 zł (w przypadku jednoosobowego gospodarstwa domowego) i np. $464 \mathrm{zl}$ (w przypadku czteroosobowej rodziny) miesięcznie musiało przeżyć prawie 130 tys. osób (tyle wynosiła w Polsce w tym czasie granica skrajnego ubóstwa, inaczej - minimum egzystencji) [Prawie 11 procent..., 2016].

Ubóstwo jest najczęstszym powodem korzystania z pomocy społecznej w województwie podlaskim. Analiza informacji uzyskanych z ośrodków pomocy społecznej i opublikowanych przez Regionalny Ośrodek Polityki Społecznej w Białymstoku ukazuje, że w 2016 r. wsparciem z tytułu ubóstwa w województwie podlaskim objęto 27180 rodzin. Zauważalny jest spadek w stosunku do 2015 r. o 1773 rodziny, czyli o ponad 6\% [Analiza poziomu..., 2017, s. 26].

Bezpieczeństwo żywności, jako trzeci warunek bezpieczeństwa żywnościowego, obejmuje przede wszystkim jakość środków spożywczych, ich walory odżywcze oraz zgodność ze standardami handlowymi i rynkowymi. Industrializacja i intensyfikacja produkcji żywności, liberalizacja handlu, proces globalizacji i towarzysząca mu większa anonimowość producentów a także pojawianie się nowych czynników chorobotwórczych, to niektóre uwarunkowania zagrażające bezpieczeństwu żywności $[Z$ badań nad..., 2015, s. 35-96]. Z uwagi na rangę tego zagadnienia rządy państw dążą do stworzenia systemu instytucji, który regulowałby sprawy żywności. Szczególne znaczenie mają w tym zakresie przepisy prawa oraz instytucje powołane do nadzoru nad ich wykonaniem.

W Polsce realizacja postanowień ustawy o bezpieczeństwie żywności i żywienia [Ustawa..., 2006] zajmują się przede wszystkim Państwowa Inspekcja Sanitarna i Inspekcja Weterynaryjna. Z danych zawartych w sprawozdaniach z realizacji zadań tychże instytucji wynika, że podejmowane są liczne działania mające na celu wzrost jakości zdrowotnej polskiej żywności. Po 2010 r. wzrasta liczba obiektów produkcji i obrotu żywnościa z wdrożonymi zasadami Dobrej Praktyki Produkcyjnej i Dobrej Praktyki Higienicznej oraz systemu HCCP. Maleje także odsetek obiektów o złym stanie sanitarnym [Kozłowska-Burdziak, 2014, s. 156].

Analizując odsetek zakwestionowanych przez Państwową Inspekcję Sanitarną prób żywności należy stwierdzić, iż od 2001 r. ulega on systematycznemu obniżeniu, co świadczyć może o poprawie jakości zdrowotnej żywności. Wyraźnie wyższą jakością zdrowotną od 2005 r. charakteryzują się produkty żywnościowe krajowe

3 Za granicę ubóstwa skrajnego uznaje się minimum egzystencji, które wyznacza poziom zaspokojenia potrzeb, poniżej którego występuje biologiczne zagrożenie życia oraz rozwoju psychofizycznego człowieka. 
w porównaniu do produktów importowanych (rysunek 2). Pierwsze lata po akcesji Polski do UE to widoczny wzrost udziału próbek zakwestionowanych w odniesieniu do produktów pochodzacych z importu. Nie dotyczy to jednak produktów rolnospożywczych nabywanych w państwach UE. Dane Państwowej Inspekcji Sanitarnej wskazuja, że od 2007 r. (od tego czasu są prezentowane dane dotyczące produktów z UE) odsetek zakwestionowanych prób żywności zakupionej w UE jest niższy niż żywności krajowej. Dane za 2016 r. wykazuja pogorszenie jakości zdrowotnej badanej żywności, zarówno krajowej, jak i pochodzącej z państw UE. Taka sytuacja utrzymała się także w roku 2017.

RYSUNEK 2

Zakwestionowane próbki żywności przez Państwową Inspekcję Sanitarną w latach 2001-2017 (w \%)

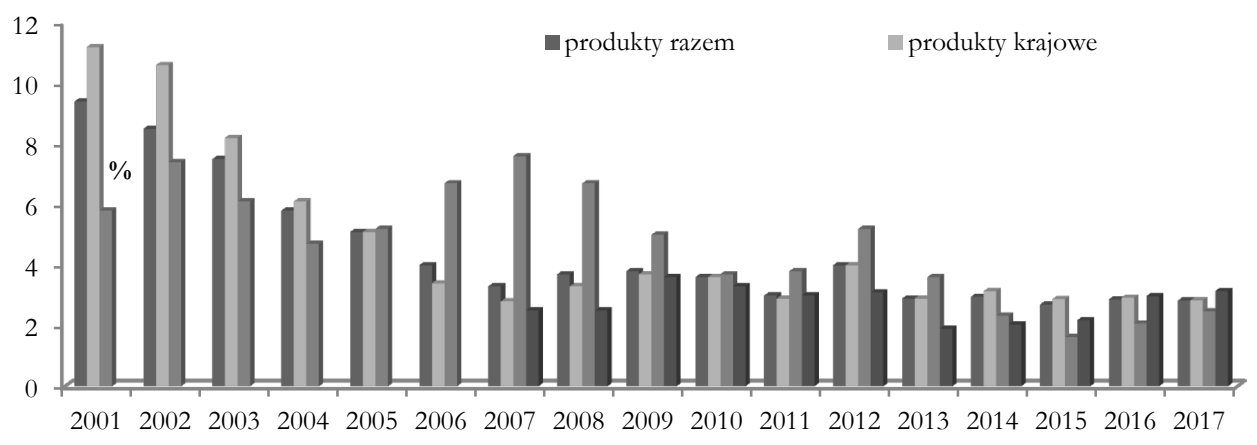

Źródło: opracowanie własne na podstawie: [Stan sanitarmy kraju, 2007-2018].

Sytuacja pod względem jakości zdrowotnej produktów pochodzenia zwierzęcego jest zróżnicowana $\mathrm{w}$ zależności od rodzaju produktu oraz podmiotu, który podlega badaniu. W przypadku badań prowadzonych w ramach nadzoru urzędowego zwraca uwagę stosunkowo wysoki odsetek zakwestionowanych prób mięsa drobiowego i produktów wytwarzanych z tego mięsa. $\mathrm{Na}$ tle pozostałych produktów wyróżnia się także wysoki odsetek prób niespełniających wymogów mleka surowego i produktów z tego mleka [Kozłowska-Burdziak, 2014, s. 156].

Analiza danych Państwowej Inspekcji Sanitarnej i Inspekcji Weterynaryjnej dowodzi, że jakość produktów żywnościowych jest zróżnicowana i trudno jest określić wyraźną tendencję jej poprawy. Również jakość handlowa artykułów rolnospożywczych jest różna w poszczególnych latach analizy. Zwraca uwagę np. wysoki poziom zafałszowania żywności [Kowalczyk, 2014, s. 150]. Sytuacja przedstawia się szczególnie niekorzystnie w zakresie znakowania produktów i parametrów fizykochemicznych żywności, określanych przez badania laboratoryjne (rysunek 3).

W 2017 r. widoczne jest wyraźne pogorszenie jakości handlowej artykułów rolno-spożywczych w porównaniu do 2016 r. (dotyczy wszystkich cech przedstawionych na rysunku 3). W największym stopniu pogorszyło się znakowanie 
produktów. W 2017 r. wskaźnik nieprawidłowości w tym zakresie zwiększył się o prawie 4 p.p. względem $2016 \mathrm{r}$.

RYSUNEK 3

Udział (\%) kontrolowanych partii żywności z nieprawidłowościami w poszczególnych obszarach kontroli (w latach 2010-2017)

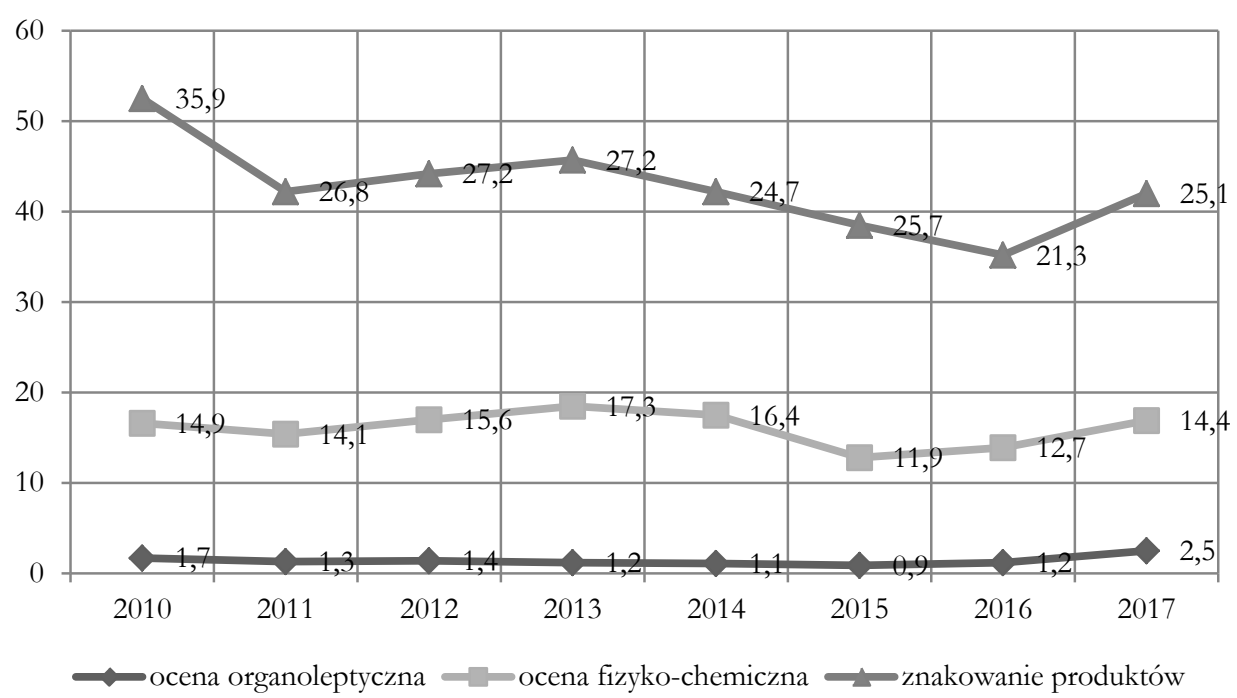

Źródło: opracowanie własne na podstawie: [Sprawozdania Inspekcii Jakości..., 2011-2018].

W województwie podlaskim w 2017 r. najczęściej występująca przyczyną kwestionowania żywności były zanieczyszczenia mikrobiologiczne (55,6\% zakwestionowanych prób żywności). Nieprawidłowe znakowanie produktów to prawie $41 \%$ zakwestionowanych przypadków [Ocena stanu..., 2018, s. 56]. Pozostałe czynniki wpływające na kwestionowanie próbek żywności miały stosunkowo niewielkie znaczenie, np. zanieczyszczenie pestycydami $-2,1 \%$, niewłaściwe cechy organoleptyczne $-2,0 \%$.

Do najczęściej odnotowywanych nieprawidłowości w podlaskich zakładach sektora spożywczego, skontrolowanych w 2017 r., należały [Ocena stanu..., 2018, s. 54]:

- niewłaściwa jakość zdrowotna środków spożywczych wprowadzanych do obrotu - szczególnie przekroczenie terminów przydatności do spożycia lub daty minimalnej trwałości,

- nieprawidłowe, niezgodne ze wskazaniami producenta warunki przechowywania żywności,

- niewłaściwe warunki ekspozycji i sprzedaży produktów spożywczych, związane m.in. z narażeniem na zanieczyszczenia z otoczenia, 
- nieprawidłowo prowadzona kontrola wewnętrzna oparta na zasadach Dobrej Praktyki Produkcyjnej, Dobrej Praktyki Higienicznej i systemie HCCP,

- brak informacji dla klientów o składzie produktu spożywczego, w tym informacji o alergenach,

- niewłaściwy stan sanitarno-techniczny zakładów produkujących żywność,

- brak dokumentacji potwierdzającej prowadzenie badań zgodności produkowanych środków spożywczych z kryteriami mikrobiologicznymi, określonymi w przepisach UE.

Specyficzną cechą rolnictwa województwa podlaskiego, która niewatpliwie może mieć wpływ na wysoką jakość zdrowotną produktów, jest wysoka dynamika rozwoju gospodarstw ekologicznych. W $2016 \mathrm{r}$. liczba gospodarstw z certyfikatem i w trakcie przestawiania na metody ekologiczne wynosiła 3437 (drugie miejsce województwa podlaskiego po województwie warmińsko-mazurskim). Pod względem udziału użytków ekologicznych $(5,3 \%)$ podlaskie zajmuje 4. miejsce w kraju (po województwach: zachodniopomorskim, lubuskim, warmińsko-mazurskim). W regionie brakuje jednak zakładów przetwórczych i zorganizowanego rynku zbytu produktów ekologicznych, współpracy producentów oraz promocji tych produktów. Województwo podlaskie zajmuje czołowe miejsce $\mathrm{w}$ kraju pod względem produkcji mleka, tymczasem wielkość produkcji krowiego mleka w gospodarstwach ekologicznych plasuje województwo dopiero na dziewiątej pozycji. Nie ma tu zlokalizowanych przetwórni mleka ekologicznego, natomiast przetwórstwo owoców i warzyw wynosiło w roku 2014 zaledwie jedną tonę (384 tys. ton w całym kraju) podczas, gdy ich produkcja wyniosła 560 ton [Raport o stanie..., 2017, s. 39].

RYSUNEK 4

\section{Liczba powiadomień w ramach systemu RASFF w latach 2005-2017}

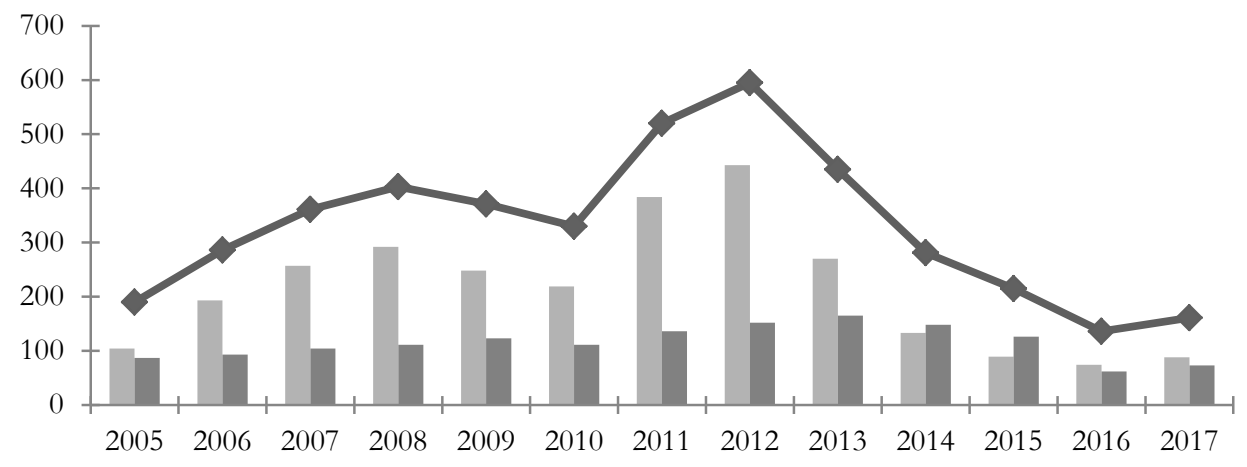

krajowe (national) pozakrajowe(foreign)

Źródło: opracowanie własne na podstawie: [Stan sanitarny kraju, 2007-2018]. 
Minimalizowaniu zagrożeń dla zdrowia i życia konsumentów, występujących w żywności, służyć ma System Wczesnego Ostrzegania o Niebezpiecznej Żywności i Paszach - RASFF. Służy on wymianie informacji pomiędzy organami urzędowej kontroli jakości żywności o potencjalnie niebezpiecznych dla konsumentów produktach żywnościowych, paszy a także materiałach do kontaktu z żywnością oraz o działaniach, które sa podejmowane w sytuacji stwierdzenia omawianych nieprawidłowości. Liczba zgłoszonych powiadomień zarówno przez krajowe organy urzędowej kontroli jakości żywności i pasz, jak i przez inne państwa członkowskie sieci RASFF w odniesieniu do polskich produktów była w latach 2005-2017 zróżnicowania (rysunek 4). Do roku 2012 wykazuje wyraźną tendencję wzrostowa, po czym liczba powiadomień wyraźnie maleje, co świadczy o poprawie jakości produktów spożywczych.

Większość produktów zgłoszonych do systemu RASFF przez Polskę w 2017 r. pochodziło spoza Unii Europejskiej, przede wszystkim z Chin, Indii i Stanów Zjednoczonych. Wśród produktów pochodzących z UE, najwięcej produktów zgłoszonych przez Polskę do RASFF dotyczyło produktów krajowych. Najczęściej identyfikowane zagrożenie, będące przyczyną zgłoszenia do RASFF powiadomień dotyczących produktów z Polski, dotyczyło występowania bakterii Salmonella, przede wszystkim w mięsie drobiowym i produktach pochodnych oraz wołowym i wieprzowym mięsie mielonym.

\section{Podsumowanie}

Przeprowadzona analiza danych źródłowych i opracowań naukowych, dotyczących kształtowania się bezpieczeństwa żywnościowego Polski pozwala stwierdzić, że:

1. Fizyczna dostępność żywności, która przede wszystkim określa wysokość krajowej produkcji rolnej, nie jest zagrożona. Także dodatnie i rosnące saldo handlu zagranicznego Polski produktami rolno-spożywczymi świadczy o występujących nadwyżkach żywności. Należy jednak mieć na uwadze możliwość wystapienia niekorzystnych zjawisk atmosferycznych, których skutki mogą dotyczyć znacznych obszarów naszego kraju. W takiej sytuacji gromadzone zapasy wydają się być jedynym gwarantem zapewnienia niezbędnej żywności dla ludności w kraju.

2. W produkcji żywności istotną rolę odgrywa województwo podlaskie, szczególnie w zakresie produkcji mleka i jego przetworów. Istotny potencjał w produkcji wysokiej jakości żywności stanowia gospodarstwa ekologiczne, których liczba plasuje województwo podlaskie w czołówce kraju. Słabo rozwinięte przetwórstwo tych produktów ogranicza jednak ich dostępność na rynku.

3. Warunek ekonomicznej dostępności żywności zarówno w całej Polsce, jak i w województwie podlaskim nie jest spełniony. Ponad 7\% ludności żyje poniżej poziomu minimum egzystencji, ponad 5\% gospodarstw domowych 
nie ma środków finansowych na zakup żywności. Dla tej grupy społecznej żywność jest za droga. Równocześnie na dużą skalę występuje zjawisko marnotrawienia żywności.

4. Jakość zdrowotna produktów rolno-spożywczych w Polsce jest zróżnicowana i nie ma stałej tendencji do poprawy. Wskazuje to na konieczność ciagłego nadzoru nad procesem produkcji i dystrybucji żywności w celu zapewnienia jej bezpieczeństwa.

5. Ocena jakości handlowej żywności dowodzi, że najwięcej nieprawidłowości dotyczy znakowania produktów. Najmniej zastrzeżeń dotyczy oceny organoleptycznej - po 2006 r. udział partii żywności ze stwierdzonymi nieprawidłowościami w tym względzie kształtuje się na poziomie od $1 \%$ do $2 \%$. Ocena pod względem parametrów fizyko-chemicznych wskazuje na rosnący udział partii żywności z nieprawidłowościami (z 11,9\% w 2015 r. do 14,4\% w 2017 r.) (fałszowanie żywności).

Przedstawione powyżej, w wielkim skrócie, tendencje w zakresie bezpieczeństwa żywnościowego dowodza, że problematyka jest ważna i ciagle aktualna. Mimo braku wyraźnych zagrożeń dla poziomu tego bezpieczeństwa w Polsce należy mieć na uwadze fakt, że nie jest to sytuacja stała i niezmienna, także w przyszłym okresie.

\section{Literatura}

Analiza poziomu ubóstwa w województwie podlaskim w latach 2015-2016, 2017, Regionalny Ośrodek Polityki Społecznej w Białymstoku, Białystok.

Aneks do opracowania sygnalnego "Zasieg ubóstwa ekonomicznego w Polsce w 2017”, 2018, GUS, https://stat.gov.pl/files/gfx/portalinformacyjny/pl/defaultaktualnosci/ 5487/14/5/1/aneks_zasieg_ubostwa_ekonomicznego_w_polsce_w_2017.pdf [data wejścia: 27.09.2018].

Ćwieluch J., 2011, Ile mamy w magazynach na mypadek kataklizmu? Stoliczku nakryj sie, „Polityka”, 28 marca, nr 2800.

Innowacje w stu̧̇bie zrónnoważonego wærostu: biogospodarka dla Europy, 2012, Komunikat Komisji do Parlamentu Europejskiego, Rady, Europejskiego Komitetu Ekonomiczno-Społecznego i Komitetu Regionów, Komisja Europejska, Bruksela, httpec.europa.euresearchbioeconomypdf201202_innovatingsustainablegrowth.pl. pdf [data wejścia 28.09.2017].

Jakość sycia w Polsce, 2015, GUS, Warszawa.

Kowalczyk S., 2014, Bezpieczeństwo i jakosść polskiej ṡymności, „Roczniki Naukowe Stowarzyszenia Ekonomistów Rolnictwa i Agrobiznesu", t. 16, z. 4, s. 147-152.

Kowalczyk S., 2016, Bezpieczeństwo i jakosśc šnnności, Wydawnictwo Naukowe PWN, Warszawa.

Kozłowska-Burdziak M., 2014, Instytucjonalny mymiar bespieczeństwa ṡynności w Polsce, „Roczniki Naukowe Stowarzyszenia Ekonomistów Rolnictwa i Agrobiznesu”, t. 16 , z. 4, s. 153-158. 
Kraciuk J., 2015, Bezpieczeństwo symnościowe z perspektyny krajón stabo $i$ mysoko rozwinietych, „Roczniki Naukowe Stowarzyszenia Ekonomistów Rolnictwa i Agrobiznesu", t. 17, z. 3, s. 205-209.

Kwasek M., 2016, Zrównoważona konsumpcja ṡywności sposobem na żmniejszenie marnotrawstwa ṡywności, IERiGZ̈-PIB, Jachranka.

Ludność. Stan i struktura oraz ruch naturalny w przekeroju terytorialnym, 2006-2018, GUS, Warszawa.

Małysz J., 2009, Ekonomiczna interpretacja beapieczeństwa ṡywnościowego, [w:] Beapieczeństwo symności w erze globalizacij, Kowalczyk S. (red.), SGH, Warszawa.

Marzęda-Młynarska K., 2014, Globalne zarz̨adzanie bezpieczeństwem ṡymnościonym na przetomie XX i XXI wieku, Wydawnictwo Uniwersytetu Marii Curie-Skłodowskiej, Lublin.

Ocena stanu sanitarnego województwa podlaskiego za 2017 rok, 2018, Państwowa Inspekcja Sanitarna Województwa Podlaskiego, Białystok.

Polska nie ma właścinych rezern strategicznych, 2016, http://www.farmer.pl/finanse/ polska-nie-ma-wlasciwych-rezerw- strategicznych,62564,1.html [data wejścia 21.06.2016].

Polski handel zagraniczny produktami rolno-sposiyncsymi w okresie styczen-kewiecień 2018 roku, 2018. Krajowy Ośrodek Wsparcia Rolnictwa, Warszawa, http://www.kowr.gov. $\mathrm{pl} /$ uploads/pliki/analizy/handel_zagraniczny/Handel\%20zagraniczny $\% 20 z a \% 2$ 04\%20miesi \%C4\%85ce\%202018\%20r.pdf [data wejścia: 16.10.2018].

Prawie 11 procent mieszkańcón województwa podlaskiego s̀jje w skrajnej nedzy, 2016, http:// www.wspolczesna.pl/wiadomosci/region/a/dane-gus-prawie-11-procmieszkancow-woj-podlaskiego-zyje-w-skrajnej-nedzy,10121620 [data wejścia 12.05.2016].

Prognoza ludności na lata 2014-2050, 2014, GUS, Warszawa.

Raport o stanie rolnictwa ekologicznego w Polsce w latach 2015-2016, 2017, Inspekcja Jakości Handlowej Artykułów Rolno-Spożywczych, Warszawa.

Rocznik statystyczny wojewódz̨twa podlaskiego, 2017, Urząd Statystyczny w Białymstoku.

Rolnictwo, 2007-2018, GUS, Warszawa.

Rolnictwo w wojewódzৃtwie podlaskim w 2016 roku, 2017, Urząd Statystyczny w Białymstoku, Białystok.

Rozporządzenie Rady (EWG) nr 315/93 z dnia 8 lutego 1993 roku, ustanawiające procedury Wspólnoty $\mathrm{w}$ odniesieniu do substancji skażających w żywności, Dz.Urz. L 37 z 13.02.1993 r.

Sprawozdania Inspekcii Jakości Handlowej Artykutów Rolno-Sposiynwcsych. Stan sanitarmy kraju, 2011-2018, Państwowa Inspekcja Sanitarna, Główny Inspektorat Sanitarny, Warszawa.

Stan sanitarny kraju, 2007-2018, GIS, Warszawa

Sustainable Agriculture Foresty and Fisheries in the Bioeconomy a Challenge for Europe, 2015, European Commission, Brussels.

Ubóstwo ekonomiczne w Polsce w 2014 roku, 2015, GUS, Warszawa.

Ustawa z dnia 25 sierpnia 2006 r. o bezpieczeństwie żywności i żywienia, Dz.U. $2006 \mathrm{nr}$ 171, poz. 1225. 


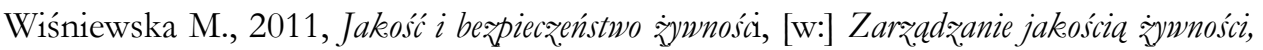
Systemy, Koncepcje, Instrumenty, Wiśniewska M., Malinowska E., Difin, Warszawa.

$Z$ badañ nad rolnictwem spotecznie zrównoważonym. Analiza bezpieczeñstwa ṡywnościowego Polski, 2015, Kwasek M. (red.), IERiGŻ-PIB, Warszawa. 